\title{
Erratum to: Involvement of Neurotransmitters in the Action of the Nociceptin/Orphanin FQ Peptide-Receptor System on Passive Avoidance Learning in Rats
}

\author{
Miklós Palotai · Ágnes Adamik · Gyula Telegdy
}

Published online: 18 July 2014

(C) Springer Science+Business Media New York 2014

\section{Erratum to: Neurochem Res}

\section{DOI 10.1007/s11064-014-1337-8}

In the original publication of the article, the authors had erroneously presented that the action of orphan GPCR
SP9155 P550 was mediated through the NOP receptor. It should actually be mediated through GPR103 receptor.

The online version of the original article can be found under doi:10. 1007/s11064-014-1337-8.

M. Palotai · Á. Adamik · G. Telegdy ( $\square)$

Department of Pathophysiology, Faculty of Medicine, University

of Szeged, Semmelweis Str. 1, Szeged 6701, Hungary

e-mail: telegdy.gyula@med.u-szeged.hu

G. Telegdy

MTA-SZTE Neuroscience Research Group of the Hungarian

Academy of Sciences, Szeged, Hungary 